\title{
TRANSFORMASI ARSIP DI ERA BIG DATA
}

\author{
YUSPIANI, WAHYUDDIN, MUHAMMAD SHABIR U. \\ Fakultas Tarbiyah dan Keguruan, Universitas Islam Negeri Alauddin Makassar \\ Email: yuspiani@uin-alauddin.ac.id, wahyuddin.naro@uin-alauddin.ac.id, \\ mshabiru@uin-alauddin.ac.id
}

\author{
(Article History) \\ Received March 23, 2021; Revised June 08, 2021; Accepted June 13, 2021
}

\begin{abstract}
Archive Transformation in the Era of Big Data
One of the technological sophistications that can be used to manage archives is Big Data which can be used efficiently, accurately in predicting and recommending systems. The problem posed in this study is how the concept of using Big Data in archive management in schools is. The type of research used is descriptive qualitative, with a phenomenological approach. The collection technique used participatory observation. From the data collected, it shows that the analysis of the 3V (Volume, Variety, Velocity) big data model for managing records in schools has met the big data model. That is, the electronic management of school records has its own characteristics such as the physical structure it has, with the physical structure owned cannot be directly seen so that its use always requires a computer system to be able to read its physical structure. The need for computers requires adjustments to the school's budget protocol. Because the costs incurred also require a fairly high budget. Therefore, the right keyword for the 4.0 era is collaboration.
\end{abstract}

Keywords: Big Data, Electronic Archives, Computer, Collaboration

\begin{abstract}
Abstrak: Transformasi Arsip di Era Big Data
Salah satu kecanggihan teknologi yang dapat dimanfaatkan untuk mengelola arsip adalah Big Data yang dapat dipergunakan secara efisien, akurasi dalam melakukan prediksi dan sistem rekomendasi. Adapun masalah yang diajukan dalam penelitian ini adalah "Bagaimana konsep penggunaan Big Data dalam pengelolaan arsip di sekolah?". Jenis penelitian yang digunakan adalah deskriptif kualitatif dengan menggunakan pendekatan fenomenologi. Teknik pengumpulan menggunakan observasi partisipasi. Dari data yang dikumpulkan menunjukkan bahwa analisis model data besar 3V (Volume, Variety, Velocity) pengelolaan arsip di sekolah telah memenuhi model big data. Artinya, pengelolaan arsip sekolah secara elektronik memiliki karakteristiknya sendiri seperti struktur fisik yang dimiliki, dengan struktur fisik yang dimiliki tidak dapat langsung dilihat sehingga untuk penggunaannya selalu memerlukan sistem komputer untuk dapat "membaca" struktur fisiknya. Kebutuhan terhadap komputer mengharuskan penyesuaian dengan protokol anggaran yang dimiliki sekolah sebab biaya yang ditimbulkan juga membutuhkan anggaran yang cukup tinggi. Oleh karena itu, kata kunci yang tepat untuk era 4.0 ialah kolaborasi.
\end{abstract}

Kata Kunci: Big Data, Arsip Elektronik, Komputer dan Kolaborasi 


\section{PENDAHULUAN}

ra 4.0 datang membawa sebuah fenomena yang berpotensi membuat mesin dapat berkomunikasi dan terhubung ke dalam sistem data besar (Big Data) dan memunculkan istilah smart dalam berbagai aspek. Kata kunci dari semua itu adalah kolaborasi, yaitu kolaborasi dalam memasuki era industri 4.0 yang saat ini telah mengubah cara kerja di semua sektor termasuk di pemerintah (Wildan et al., 2021: 1).

Langkah awal dari kolaborasi yang dilakukan oleh pemerintah adalah dengan mengeluarkan Peraturan Pemerintah Nomor 95 Tahun 2018 tentang Sistem Pemerintahan Berbasis Elektronik (RI, 2020). Dari langkah awal tersebut, setiap instansi pemerintah wajib menyediakan informasi, mengelolanya, menganalisisnya sampai pelaksanaan dalam bidang penyelenggaraan kearsipan. Tidak heran jika banyak staf atau pimpinan yang bekerja di depan layar komputer yang menyebabkan pergeseran cara kerja manual menjadi cara kerja yang memanfaatkan kecanggihan teknologi (Adrian, 2016: 6). Pernyataan tersebut mengindikasikan bahwa pengelolaan arsip secara elektronik telah menjadi tren baru sekaligus fokus inovasi di banyak instansi, termasuk instansi pendidikan.

Keberadaan arsip dalam dunia pendidikan, khususnya sekolah, merupakan identitas penting yang menunjukkan bukti legalitas kepada seseorang. Jika ada alumni yang mendaftar PNS, data yang diminta tidak cukup dengan legalisir ijazah, sistem kemudian mengonfirmasi beberapa data penting seperti nomor seri ijazah, data alumni yang terhubung ke dalam data induk sekolah, akreditasi sekolah, dan lain sebagainya. Ilustrasi tersebut membuktikan bahwa bangunan arsip telah berubah menjadi sebuah bangunan virtual yang dianggap lebih sesuai dengan kebutuhan saat ini yang semakin cepat "berbagi" (konfirmasi) dan fleksibilitas dalam berjejaring. Hal tersebut bukan lagi sebatas konsep, tetapi sesuatu yang sedang kita hadapi sejak awal tahun 2011 sampai sekarang. Meskipun demikian, permasalahan klasik masih saja terus terjadi.

Arsip juga memiliki makna konotasi sama halnya dengan informasi, tidak semua informasi dapat dikonsumsi, begitu pula dengan arsip. Berdasarkan hal tersebut, dapat dipahami bahwa ada sejumlah arsip yang masih dipergunakan secara langsung dalam kegiatan organisasi. Oleh karena itu, arsip tersebut harus dikelola dengan baik untuk mendukung aktivitas organisasi, salah satu bentuk pengelolaannya dengan cara memanfaatkan kecanggihan teknologi. Salah satu kecanggihan teknologi yang dapat dimanfaatkan secara efisien adalah Big Data, akurasi dalam melakukan prediksi dan sistem rekomendasi (Kristiyanti, 2017: 86).

Berdasarkan uraian di atas, penulis tertarik untuk mengkaji secara ilmiah beberapa topik yang berkaitan dengan "arsip" dan "teknologi". Adapun masalah yang diajukan dalam tulisan ini ialah "Bagaimana penggunaan Big Data dalam pengelolaan arsip di sekolah?". Untuk menjawab masalah tersebut, peneliti menggunakan jenis penelitian deskriptif kualitatif dengan melakukan pendekatan 
fenomenologi. Tujuannya untuk mendapatkan informasi mengenai pemanfaatan teknologi informasi dalam pengelolaan arsip di sekolah. Informasi yang didapat kemudian dijelaskan dengan menggunakan analisis $3 \mathrm{~V}$ yaitu volume, velocity dan variety.

\section{PEMBAHASAN}

\section{Pengertian Arsip dan Arsip Elektronik}

Sebelum memulai pembahasan dalam tulisan ini, terlebih dahulu ada beberapa istilah yang perlu untuk dipahami, seperti penjelasannya dirangkum oleh Sattar (2019: 1-3) dalam bukunya “Manajemen Arsip" menjelaskan bahwa:

"Kata arsip berasal dari bahasa Belanda yakni archief, kemudian dalam bahasa Inggris disebut dengan file, yang berasal dari bahasa Latin fiham yang berarti tali atau benang, sementara dalam kamus administrasi perkantoran file memiliki beberapa arti, di antaranya: lemari berlaci yang dipakai untuk menyimpan berkas-berkas. Selain istilah tersebut, arsip masih memiliki istilah lain yaitu warkat yang berasal dari bahasa Arab yang berarti surat, namun seiring berjalannya waktu warkat tidak hanya sebatas surat melainkan lembaran yang berisi keterangan yang mempunyai arti dan kegunaan".

Menurut Abdillah dan Prasetya dalam Rosalin (2017: 1) menyebutkan bahwa istilah arsip berawal dari banyaknya dokumen yang dibuat oleh pemerintah. Secara singkat dapat dikatakan bahwa arsip bermakna rekaman, catatan atau berkas yang telah dibuat oleh organisasi, sementara arsip dalam Kamus Lengkap Bahasa Indonesia memiliki arti dokumen yang disimpan sebagai referensi, dokumen berupa surat atau akta dan sebagainya yang dikeluarkan oleh instansi resmi. Menurut Barthos, arsip adalah sebuah catatan tertulis, baik berbentuk gambar yang berisi informasi penting, atas aktivitas yang telah dilakukan oleh organisasi (Barthos, 2013: 2).

Menurut Weisinger dalam Muhidin dan Winata (2016: 21), arsip memiliki bagian dari semua dokumen masuk maupun keluar yang dibuat oleh organisasi atau perusahaan dengan informasi yang terkandung di dalamnya, berisi tentang tindakan, keputusan, serta operasi yang telah terjadi dalam suatu organisasi. Dengan demikian, setiap dokumen yang memiliki informasi penting yang bermanfaat di masa lalu, di masa sekarang dan di masa yang akan datang. Dalam Undang-Undang Nomor 43 Tahun 2009 tentang Kearsipan, Rosalin (2017: 2) menjelaskan bahwa pengertian arsip adalah:

"Rekaman kegiatan atau peristiwa dalam berbagai bentuk dan media sesuai dengan perkembangan teknologi informasi dan komunikasi yang dibuat dan diterima oleh lembaga negara, pemerintah daerah, lembaga pendidikan, perusahaan, organisasi politik, organisasi kemasyarakatan dan perorangan dalam pelaksanaan kehidupan bermasyarakat, berbangsa dan bernegara". 
Arsip elektronik bagi masyarakat awam dipahami sebagai arsip yang dibuat melalui mesin elektronik, tetapi ada juga masyarakat awam yang memahami arsip elektronik sebagai arsip yang diciptakan dan pengelolaannya memanfaatkan sistem komputer. Menurut Perka ANRI Nomor 15 Tahun 2012 menyebutkan bahwa surat elektronik adalah surat yang diciptakan dalam format elektronik (Sattar, 2019: 123-124). Selanjutnya Sattar menambahkan bahwa dalam Undang-Undang Nomor 11 Tahun 2008 tentang Informasi dan Transaksi Elektronik, istilah arsip elektronik dikenal sebagai dokumen elektronik yang didefinisikan sebagai berikut:

"Setiap informasi elektronik yang dibuat, diteruskan, dikirimkan, diterima atau disimpan dalam bentuk analog, digital, elektromagnetik, optikal atau sejenisnya, yang dapat dilihat, ditampilkan dan didengar melalui komputer atau sistem elektronik, termasuk tulisan, audio, gambar, peta, rancangan, foto atau sejenisnya, huruf, tanda, angka, kode akses, simbol atau perforasi yang memiliki makna atau arti atau dapat dipahami oleh orang yang mampu memahaminya" (Sattar, 2019: 124).

Penjelasan tersebut menunjukkan bahwa arsip dapat dipahami sebagai informasi yang menunjukkan rekam jejak suatu organisasi dan disimpan dengan menggunakan media.

\section{Istilah Big Data}

Istilah Big Data atau data besar merupakan data yang memiliki ukuran yang sangat besar mulai dari data yang terstruktur sampai data yang tidak terstruktur. Sampai saat ini, big data banyak dimanfaatkan dalam kegiatan organisasi pada umumnya (Buslim \& Iswara, 2019: 80). Sementara Wijaya (2019: 1) memahami istilah big data sebagai kumpulan data yang sangat besar, tetapi dapat diproses dengan menggunakan teknologi pengolahan data secara konvensional sehingga big data dapat dianalisis secara lebih sederhana ke dalam tiga karakteristik, yaitu volume, variety dan velocity. Jika pernyataan tersebut diterjemahkan secara sederhana, big data merupakan data dengan kapasitas besar.

Menurut Hamzah, ada sejumlah fakta yang dapat digunakan untuk memahami istilah big data secara lebih sederhana, yaitu media sosial seperti Facebook. Facebook sampai saat ini memiliki banyak pengguna aktif yang tersebar di seluruh dunia bahkan untuk satu harinya, Facebook dapat memproses data kurang lebih 10 terabyte bahkan lebih (Wijaya, 2019: 15). Tidak heran jika Facebook dapat mengabadikan setiap momen penting dan menghadirkannya kembali. Dari ilustrasi tersebut, mungkinkah dengan skala terabyte atau petabyte per hari dapat dikategorikan sebagai data yang berkapasitas besar?. Lalu, bagaimana dengan Google?. Perjalanan Google yang dimuat dalam salah satu halaman berita online wartaekonomi.co.id menjelaskan:

"Sejak berdirinya, Google telah dilengkapi dengan teknologi PageRank, teknologi Crawler, teknologi sistem penyimpanan data (Google File 
System), teknologi pengolahan data (MapReduce) dan teknologi Bigtable yang mampu menyajikan data yang berukuran raksasa" (Warta Ekonomi, 2019).

Berdasarkan ilustrasi tersebut, Wijaya (2019: 33) mengakui bahwa Google telah menyadari potensi jika memproses big data, sehingga jauh sebelum istilah big data mulai dibicarakan, Google lebih dulu menggali potensi tersebut. Namun, untuk memulai menggali potensi yang dimiliki big data, terlebih dahulu harus memahami big data yang sebenarnya, mungkinkah dengan skala terabyte atau petabyte cukup representatif dalam mewakili data yang berukuran besar?. Saat ini, fakta yang sering dijumpai ialah kebiasaan browsing internet. Kebiasaan tersebut mengakibatkan permintaan data menjadi semakin besar. Besarnya permintaan memungkinkan sampai pada skala terabyte atau petabyte. Kesimpulannya hanya sampai pada pengakuan sebuah keberadaan data dengan kapasitas yang cukup besar. Tidak heran jika Wijaya merangkum laporan McKinsey Global Institute, yang dirilis pada Mei 2011, yang menyebutkan:

"Big data adalah data yang sudah sangat sulit untuk dikoleksi, disimpan, dikelola maupun dianalisa dengan menggunakan sistem database biasa karena volumenya yang terus berlipat-lipat" (Wijaya, 2019: 9).

Apabila kesimpulan yang didapat hanya sampai pada keberadaan sebuah data dengan kapasitas besar, setiap keberadaan memiliki karakteristik dan karakteristik tersebut sudah cukup membantu dalam memahami istilah big data. Gartner dalam Wijaya (2019: 9) menyebutkan bahwa istilah big data memiliki tiga karakteristik yang dikenal dengan istilah 3V yaitu Volume, Variety dan Velocity. Istilah pertama yang disebutkan ialah volume yang menjelaskan sebuah ukuran data dengan kapasitas besar, kemudian yang kedua ialah variety yang menjelaskan bahwa data memiliki jenis yang sangat beragam, dan istilah terakhir yang disebutkan ialah velocity yang diartikan kecepatan dalam memproses sebuah data untuk memberikan hasil yang valid.

\section{Manajemen Kearsipan Elektronik}

Arsip menunjukkan kepentingan organisasi dan pemangku kepentingan, seperti kepemilikan, aset, keuangan, dan lain sebagainya. Oleh karena itu, arsip harus dikelola dengan baik sesuai dengan amanah Undang-Undang Nomor 43 Tahun 2009 tentang Kearsipan yang bertujuan untuk membantu serta mendukung aktivitas manajemen secara keseluruhan. Manajemen kearsipan tidak lepas dari kontrol pengawas yang secara konsisten memperhatikan daur hidup arsip. Proses pengelolaan arsip berawal dari penciptaan atau penerimaan, pemeliharaan atau penggunaan, kemudian berakhir pada penentuan tentang arsip akan tetap dijaga untuk dipermanenkan ataukah harus dimusnahkan dengan alasan sudah tidak memiliki nilai guna (Santosa, 2014: 20-21). 
Manajemen kearsipan bertujuan untuk menjamin arsip yang bersifat penting dalam sebuah organisasi agar menyimpannya dengan rapi dan tersedia saat dibutuhkan, bahkan ketika terjadi bencana alam yang menyebabkan kerusakan di mana-mana. Ruang lingkup manajemen arsip mencakup pada identifikasi dan dokumentasi arsip, menentukan cara-cara untuk melindunginya dan menjamin bahwa arsip merupakan prioritas penting yang perlu untuk diselamatkan jika terjadi bencana. Proses pengelolaan arsip dimulai pada fase arsip tersebut dibuat atau diterima. Pada fase tersebut, informasi yang akan direkam pada sebuah media yang memiliki desain dan kualitas. Pada fase tersebut juga merupakan fase pembuatan standardisasi terhadap desain formulir, contohnya "ljazah" maka jenis kertas yang digunakan berkualitas tinggi dan informasi yang tertulis dalam ijazah berasal buku induk sekolah. Dengan demikian, informasi yang direkam dapat terus dilestarikan dan menandakan nilai informasi itu penting.

Perkembangan teknologi informasi saat ini memunculkan kebiasaan baru di semua sektor, seperti di sektor pendidikan. Fakta menunjukkan kebiasaan tersebut, berupa "transaksi elektronik" dalam melakukan pembayaran sumbangan pembinaan pendidikan (SPP), pendaftaran siswa baru, serta pengurusan kartu rencana studi (KRS), dan lain sebagainya. Kenyataan tersebut menjadi dalil yang dapat menjelaskan konsep serta terobosan baru dalam pengelolaan arsip untuk melakukan pemindahan setiap catatan "transaksi elektronik" pembayaran SPP dari satu media ke media lain dengan menggunakan perangkat lunak seperti program microsoft yang dimiliki komputer. Namun, tidak sedikit pihak yang mengatakan bahwa pada aspek hukum, arsip elektronik belum dapat diakomodasi sebagai alat bukti. Berkaitan dengan hal tersebut, Rosalin (2017: 228) merangkum penjelasan Undang-Undang Nomor 11 Tahun 2008 tentang Informasi dan Transaksi Elektronik bahwa:

"Arsip dikenal sebagai dokumen elektronik yang didefinisikan sebagai informasi elektronik yang dibuat, diteruskan, dikirim, diterima atau disimpan dalam bentuk analog, digital, elektromagnetik, optikal dan sejenisnya yang dapat dilihat, ditampilkan melalui sistem elektronik".

Proses pengelolaan arsip elektronik dapat ditemui dalam berbagai bentuk perangkat lunak (software) salah satunya portable document format (PDF) yang terintegrasi ke dalam sistem personal computer (PC), sehingga jelas perbedaan dengan pengelolaan arsip manual dengan arsip elektronik pada tahap penciptaan, penyimpanan, distribusi, dan penggunaan.

Manfaat pengelolaan arsip elektronik dalam kegiatan sekolah, salah satunya ialah dapat meningkatkan akses layanan secara cepat kepada beberapa stakeholders, seperti distribusi arsip sesuai dengan kebutuhan khalayak. Contohnya, Dinas Pendidikan dan Kebudayaan yang membutuhkan informasi mengenai jumlah peserta didik yang aktif dan jumlah peserta didik yang sudah 
tamat, jumlah guru yang sesuai dengan disiplin ilmu yang diajarkan, dan lain sebagainya.

Manfaat lain dari pengelolaan arsip elektronik dikemukakan oleh Odgers bahwa salah satu keuntungan mengelola arsip elektronik adalah memberikan kemudahan dalam bekerja tanpa harus meninggalkan meja kerjanya, untuk melakukan pengindeksan menjadi lebih fleksibel dan mudah dimodifikasi. Selain itu, pencarian full-text dapat dilakukan sehingga kecil kemungkinan arsip akan hilang. Selanjutnya, tidak memakan tempat sehingga kecil kemungkinan terjadinya kerusakan pada arsip, memudahkan untuk berbagi arsip dan memudahkan dalam melakukan recovery data (Odgers, 2005: 72).

Beberapa penjelasan di atas memberikan gambaran bahwa manajemen arsip elektronik merupakan solusi atas persoalan arsip yang semakin hari semakin bertambah banyak. Melalui pengelolaan arsip secara elektronik dapat diperoleh berbagai manfaat yang mendukung terciptanya efektivitas dan efisiensi organisasi.

\section{Konsep Big Data dalam Pengelolaan Arsip Sekolah dengan Analisis 3V}

Analisis model 3V terdiri dari Volume, Variety dan Velocity. Data yang dianalisis terdiri dari data atau arsip yang berbentuk teks PDF, video, rekaman audio, gambar, dan sebagainya. Bentuk data tersebut merupakan data yang memiliki ukuran besar. Data atau arsip yang terkumpul kurang lebih berjumlah 940 pada fase awal pembuatan arsip, termasuk arsip yang bersumber dari sistem informasi lainnya seperti media sosial yang dimiliki sekolah, di antaranya group WhatsApp, Facebook, Instagram, dan Email (Saluky, 2017: 27). Pernyataan tersebut sejalan dengan penjelasan Undang-Undang Nomor 11 Tahun 2008 tentang Informasi dan Transaksi Elektronik yang menyebutkan bahwa arsip elektronik dikenal dengan sebutan dokumen elektronik.

Analisis Variety merupakan analisis data atau arsip yang cukup bervariasi mulai dari jenis dan ukuran (volume) yang dikumpulkan. Setelah data atau arsip telah terkumpul, terdapat data terstruktur dan tidak terstruktur yang berasal dari database sistem informasi yang bersumber dari media sosial yang dimiliki sekolah. Analisis Velocity digunakan untuk mengumpulkan data atau arsip kemudian dianalisis. Hal tersebut penting dilakukan untuk dijadikan bahan pertimbangan dalam mengeluarkan keputusan. Contohnya, beberapa hasil prediksi arsip sekolah yang memerlukan akuisisi. Akuisisi dilakukan karena seiring berjalannya waktu volume arsip menjadi semakin banyak dan terus berkembang dengan cepat sehingga membutuhkan akuisisi (Nur, 2020: 28).

Analisis model $3 \mathrm{~V}$ dalam mendukung pengelolaan arsip di sekolah, dimulai pada saat arsip sekolah dibuat dengan menggunakan perangkat lunak sistem dan perangkat lunak aplikasi. Salah satu perangkat lunak sistem yang sering digunakan untuk membuat arsip online maupun offline ialah Microsoft Word, Microsoft Excel 
dan Google Docs. Sementara perangkat lunak aplikasi yang digunakan ialah open source (Wildan, et al., 2021: 1).

Pengelolaan arsip secara umum dibantu oleh dua jenis perangkat, yaitu perangkat lunak dan perangkat keras. Kolaborasi keduanya menghasilkan beberapa file yang berbentuk teks, file berbentuk data atau susunan angka-angka, gambar, serta file berbentuk audio. Seiring berjalannya waktu, volume arsip terus mengalami perkembangan dengan cepat. Besar volume arsip yang terus berkembang dengan cepat setiap harinya membutuhkan ruang penyimpanan yang berukuran cukup besar.

Salah satu program berbasis open source NoSQLd dan relational database management system (RDBMS) yang berfungsi untuk menyimpan dan mengolah berbagai jenis data atau arsip yang berukuran besar. Gabungan NoSQI dan RDBMS sudah tidak diragukan lagi jika berurusan dengan volume data yang berukuran besar, tetapi ada sesuatu yang juga menjadi kebutuhan mendasar dalam mengelola data atau arsip sekolah. Kebutuhan tersebut erat kaitannya dengan kemudahan layanan akses data atau arsip yang bebas hambatan. Contohnya, kebutuhan setiap orang tua siswa yang ingin memastikan perkembangan proses pembelajaran anaknya selama di sekolah, orang tua tinggal memasukkan beberapa susunan angka atau huruf ke dalam sebuah aplikasi. Kemudian dalam hitungan detik, semua data atau arsip yang dibutuhkan terkirim langsung ke orang tua siswa dan langsung dapat dilihat perkembangan proses pembelajaran anaknya selama di sekolah.

Jenis arsip yang penting untuk diselamatkan dalam suatu sekolah ialah bukti atau akta pendirian sekolah, surat izin operasional sekolah, buku induk siswa, surat akreditasi, buku alumni, nilai mata pelajaran dari setiap semester, dan lain sebagainya. Dari penjelasan tersebut, dapat dipahami bahwa dengan melakukan akuisisi atau penyelamatan arsip dapat menambah kekayaan khazanah arsip, sebagai bentuk pelayanan dan bentuk tanggung jawab kepada masyarakat sesuai dengan amanat Undang-Undang Nomor 43 Tahun 2009 tentang kearsipan.

Adapun rekomendasi dilakukan untuk melayani masyarakat seperti yang telah dicontohkan di pendahuluan. Jika ada alumni yang mendaftar PNS, data yang diminta tidak cukup dengan legalisir ijazah, sistem kemudian mengonfirmasi beberapa data penting seperti nomor seri ijazah, data alumni yang terhubung ke dalam data induk sekolah, akreditasi sekolah, dan lain sebagainya. Dengan demikian, dapat dipahami bahwa sifat arsip memiliki keterkaitan. Jika seorang alumni memperlihatkan legalisir ijazahnya, nama dan nomor induk atau nomor seri ijazah juga tercatat di dalam sekolah atau di portal Dinas Pendidikan dan Kebudayaan, baik itu di pusat atau di daerah. Dengan kata lain, pihak yang berkepentingan mendapatkan rekomendasi sesuai dengan keterkaitannya terhadap sejumlah arsip yang hendak dibutuhkan. Oleh karena itu, pihak yang berkepentingan memerlukan verifikasi tahap kedua. 
Berdasarkan sistem rekomendasi tersebut, pengguna diharapkan menemukan sejumlah arsip yang memiliki keterkaitan untuk dijadikan bahan pertimbangan dalam menetapkan suatu keputusan. Dengan demikian, efektivitas pekerjaan dan akurasi penggunaan teknologi informasi secara umum dapat memudahkan pelaksanaan kegiatan yang telah direncanakan. Oleh karena itu, pengelolaan arsip sekolah secara elektronik memiliki karakteristiknya sendiri, seperti struktur fisik dan logik yang dimiliki. Dengan struktur fisik yang dimiliki tidak dapat langsung dilihat dan untuk penggunaannya selalu memerlukan sistem komputer untuk dapat "membaca" struktur fisiknya. Ilustrasi tersebut menunjukkan bahwa salah satu ciri arsip di era 4.0 memerlukan komputer dalam pengolahannya.

Kebutuhan terhadap komputer mengharuskan penyesuaian dengan protokol anggaran yang dimiliki oleh sekolah. Hal tersebut disebabkan karena biaya yang ditimbulkan juga membutuhkan anggaran yang cukup tinggi. Tidak dapat dipungkiri, revolusi digital maju dengan pesat dan tata kelola arsip di sekolah harus dipacu untuk mengimbangi kecanggihan teknologi saat ini. Oleh karena itu, kata kunci yang tepat untuk era 4.0 ialah kolaborasi.

\section{PENUTUP/KESIMPULAN}

Konsep big data dalam pengelolaan arsip di sekolah dengan menggunakan analisis model data besar 3V (Volume, Variety, Velocity) menunjukkan bahwa pengelolaan arsip di sekolah telah memenuhi model big data. Artinya, pengelolaan arsip sekolah secara elektronik memiliki karakteristiknya sendiri, seperti struktur fisik yang dimiliki. Dengan struktur fisik yang dimiliki tidak dapat langsung dilihat sehingga untuk penggunaannya selalu memerlukan sistem komputer untuk dapat "membaca" struktur fisiknya. Hal tersebut menunjukkan bahwa salah satu ciri arsip di era 4.0 memerlukan komputer dalam pengolahannya.

Kebutuhan terhadap komputer mengharuskan penyesuaian dengan protokol anggaran yang dimiliki oleh sekolah karena biaya yang ditimbulkan juga membutuhkan anggaran yang cukup tinggi. Tidak dapat dipungkiri, revolusi digital maju dengan pesat dan tata kelola arsip di sekolah harus dipacu untuk mengimbangi kecanggihan teknologi saat ini. Oleh karena itu, kata kunci yang tepat untuk era 4.0 ialah kolaborasi.

\section{DAFTAR PUSTAKA}

Adrian, R. (2016). Pertanggungjawaban Pidana terhadap Pelaku Penyebar Provokasi melalui Media Sosial (Studi Putusan Pengadilan Negeri Muaro Nomor: 45/PID.B/2012/PN.MR).

Barthos, B. (2013). Manajemen Kearsipan untuk Lembaga Negara, Swasta dan Perguruan Tinggi. Jakarta: Bumi Aksara.

Buslim, N., \& Iswara, R. P. (2019). Pengembangan Algoritma Unsupervised Learning Technique pada Big Data Analysis di Media Sosial sebagai Media Promosi 
YUSPIANI, WAHYUDDIN, MUHAMMAD SHABIR U.

Online bagi Masyarakat. Jurnal Teknik Informatika, 12(1), 79-96. https://doi.org/10.15408/jti.v12i1.11342

Kristiyanti, I. (2017). Manajemen Kearsipan dalam Meningkatkan Kualitas Pelayanan. Efisiensi-Kajian IImu Administrasi, 13(2), 85-97. https://doi.org/10.21831/efisiensi.v13i2.11678

Muhidin, S. A., \& Winata, H. (2016). Manajemen Kearsipan. Bandung: Pustaka Setia.

Nur, S. K. (2020). Pemanfaatan Big Data Pada Konsep Smart City: Kajian Pustaka. Jurnal INSTEK (Informatika Sains dan Teknologi), 5(1), 27. https://doi.org/10.24252/instek.v5i1.12140

Odgers, P. (2005). Administrative Office Management: Edition 13: Short Course. Thomson/South-Western.

RI, K. S. (2020). Peraturan Presiden Republik Indonesia Nomor 95 Tahun 2018 tentang Sistem Pemerintahan Berbasis Elektronik. In Menteri Hukum Dan Hak Asasi Manusia Republik Indonesia.

Rosalin, S. (2017). Manajemen Arsip Dinamis. Malang: Universitas Brawijaya Press.

Saluky. (2017). PROCEDIAMATH The Use of Big Data for Education \& Kontribusi Matematika dalam Mempertahankan Nilai Budaya dan Sastra. Big Data Analysis on Smartcampus Applications IAIN Syekh Nurjati Cirebon: A Preliminary Study.

Santosa, H. (2014). Arsip Universitas Gajah Mada. Khazanah, 7.

Sattar. (2019). Manajemen Kearsipan. Yogyakarta: Penerbit Deepublish.

Warta Ekonomi. (2019). https://www.wartaekonomi.co.id/

Wijaya, W. M. (2019). Teknologi Big Data: Sistem Canggih di Balik Google Facebook Yahoo! IBM (Second). Yogyakarta: Budi Utama.

Wildan, R. A., Rajagede, R. A., \& Rahmadi, R. (2021). Analisis Sentimen Politik Berdasarkan Big Data dari Media Sosial Youtube : Sebuah Tinjauan Literatur. AUTOMATA, 2. 